\title{
The Influence of Financial Performance on Stock Price in Indonesian Oil and Gas Companies
}

\author{
Nurul Eka Putri Purnamasari, Imas Purnamasari, Budhi Pamungkas Gautama \\ budhipamungkas@upi.edu \\ Universitas Pendidikan Indonesia
}

\begin{abstract}
Oil and gas industry showed a declining financial performance caused by the collapse in world oil prices. The purpose of this research to know the effect of profitability and solvency on the stock price of Oil and Gas Company listed on the Stock Exchanege in The Period of 2010-2015. This research applied verification method concluded in data panel design. Total of the population there are 9 companies and total of the sample is 5 companies, were chosen as a sample using purposive sampling. The statistic analysis that was used in this study was multiple linear regression. Based on the findings, it was provable that regression statistic model could applied in noticing the effect of profitability and solvency on stock price. This research show that profitability positively affected the stock price in significant manner and solvency was did not affect negatively on the stock price.
\end{abstract}

Keywords- Debt to Equity Ratio, Financial Performance, Oil and Gas Company, Profitability, Return on Equity, Signalling Theory, Stock Price.

\section{INTRODUCTION}

One of the most important issue in field of finance research is fluctuations in stock prices. Stock prices in the capital market industry became a serious thing to be discussed [1]. The stock price may be used by investors to measure the performance of a company. The stock price is always change according to the situation [2]. It can be drawn a meaning that the stock price has an important role for investors to gauge how the performance of a company in which the company's stock price will change according to the circumstances of the company. A company that has a good performance, then the stock price will be high, otherwise if the performance of a company is not good, then the share price will be low.

In generally, the company's financial performance will affect the stock price of a company. The stock price of companies formed by the demand and supply on the stock. The better financial performance of a company then the company will get a higher value. The high value of the company will increase the trust of investors for investing in the company and with the high demand for shares from the investors will increase the company's stock prices.
Competition for oil and gas companies are increasingly high in order to compete with other companies, companies must be able to manage the entire wealth, liabilities and capital owned as much as possible so that the company's operations can run well, because the oil and gas industry in the country has an important role for a country where this industry is the second largest foreign exchange earner after taxes. About $30 \%$ of state revenue is derived from fossil fuels. The industry is not only a contributor to foreign exchange, but the upstream oil and gas sector is also a provider of energy for economic growth and the life of Indonesian society. Oil and gas industry showed a declining financial performance. The problem is caused by the collapse in world oil prices. The decline in world oil prices will have an impact on the performance of listed companies in the energy sector and commodities. World crude oil is a key indicator for the movement of commodity prices in the country. The problems regarding the stock declines also occurred in the oil and gas industry in Indonesia.

Based on these issues, the effects would make the company's oil and gas revenues decreased. This problem will make the company's stock price of oil and gas in the BEI will also decline. Some of the mining sector is experiencing serious problems one of which is the oil and gas sector.

The cause of rise and fall of the stock price performance of the company has decreased in each time [3]. The company's performance can be seen on the company's financial performance. To analyze the financial performance of the company one of the ways used is to use the analysis of financial statements. The indicators used in the analysis of the performance of companies such as liquidity, profitability, solvency, activity and market value [4]. The better company can improved their performance, then the greater the influence on stock prices. The state of the company will be the benchmark of how much risk will be borne by the investor. The indicators used in this study is the profitability and solvency.

The company's value is basically measured by various aspects one of which is the market price of shares of the company, because the company's stock 
market price reflects investors' assessment of the overall equity held [5]. The impact will be felt by companies from declining stock prices is the declining value of the company. The value of the company is very important because of the high value of the company which will be followed by a high prosperity shareholders [6]. The higher the stock price the higher the value the company. High corporate value to be the desire of the owners of the company, because with a high value indicates prosperity shareholders also high.

Profitability is one indicator of financial performance commonly be considered investor in making an investment decision A company that has the ability to generate profits well or could increase profits, then the company's stock price will rise in other words the profitability would increase stock prices [7]. Profitability can be measured by using ROA, ROE, NPM and GPM [8]. Profitability in this study was measured using the ROE.

There is one more financial performance used in this research it's called the solvency. Solvency is the ability of a company to pay its long-term liabilities. Solvency indicates the percentage of the provision of funds by the shareholders to the lender. The higher the ratio, the lower the company's funding is provided by the shareholders [9].

One of the factors that may affect the stock price movements is the proportion of the company's debt to equity [10]. Solvency ratios can be measured using some of which are DAR, DER, LTDtER, and TIE [11]. Solvency in this study was measured using DER.

A company would have to provide information to investors about how the company's condition. It is called the signaling theory. Generally, signaling theory can be regarded as information announced by the company to provide a signal to investors in the stock market in order to influence the decisions of investors in investing. The information to be received by investors, one of which is information concerning the profitability and solvency of the company, because by seeing how the profitability and solvency of the company, an investor can assess how the financial performance of the company. It would affect an investor's decision to invest. If the company has a high profitability and solvency are low, then the investor will invest in the company, and the company's stock price will rise. Conversely, if the company's profitability is low and the company's solvency is high, then an investor is less interested to invest in the company. Such conditions will have an impact on the company's stock price decline. The purpose of this study was to determine how the profitability and solvency effect on stock prices in the oil and gas companies in Indonesia listed on the Indonesia Stock Exchange or Bursa Efek Indonesia in 2010-2015.

\section{LITERATURE REVIEW}

In general, the company's financial performance will affect the stock price of a company. The stock price of companies formed by the demand and supply on the stock. The better the financial performance of a company, the company's value even higher. With the high value of the company will increase the confidence of investors for investing in the company and with the high demand for shares from the investor will increase the company's stock price.

Factors that affect stock prices, among others, the internal conditions of the company, the law of supply and demand, interest rates, foreign exchange rates, foreign funds in the stock, the stock price index, news and rumors, dividend, corporate profits, and other factors [12]. Internal factors are factors relating to the performance of the company itself. The price of a security will be affected by the performance of the company. The performance of the company itself will be affected by the condition of the industry and the economy in general. Many of the indicators used in the analysis of the performance of companies such as liquidity, profitability, solvency, activity and market value [13].

Profitability is the company's ability to generate earnings and as an end result of a number of policies and decisions made by the company. The higher the value of the profitability of a company, investors will be more interested in the company's stock. Usually a stock is very dipengaruhui by the financial performance of the companies concerned [14].

Solvency is the ability of a company to pay its long-term liabilities. Solvency influence on stock prices is if DER a company that is too high to have an adverse impact on the performance of the company, because of the higher debt levels indicating the company's interest burden will be greater and reduce profits. Solvency ratios can be measured using some of which are DAR, DER, LTDtER, and TIE [15]. Solvencyy in this study was measured using DER.

DER is a ratio used to assess the debt for equity. To look for this ratio by comparing the entire debt. Including current liabilities with the rest of the equity. This ratio is useful to know the amount of funds provided the borrower (creditor) with the owner of the company. In other words this ratio to determine every rupiah of capital itself is used as collateral for the debt.

A company would have to provide information to investors about how the company's condition. It is called the signaling theory. The information is published as an announcement will give a signal to investors in making investment decisions. If the announcement contains a positive value, it is expected that the market will react when the announcement was welcomed by the market [16].

\section{RESEARCH METHODOLOGY}

The object of this research is profitability, solvency, and stock price in oil and gas company listed on the Stock Exchange in 2010-2015. As for the independent variable in this study is the profitability $\left(\mathrm{X}_{1}\right)$, solvency $\left(\mathrm{X}_{2}\right)$ and the dependent variable is the stock price $(\mathrm{Y})$. 
This study uses a study design verification with panel data. The population in this study is 9 oil and gas company listed on the Stock Exchange, while the sample performance of this research is 5 oil and gas company listed on the Stock Exchange, especially the company's financial statements 2010-2015. In this study will be used purposive sampling technique.

\section{RESULTS AND DISCUSSIONS}

TABLE I. LINEAR REGRESSION TEST RESULTS TABLES FOR MULTIPLE

Coefficients $^{\mathrm{a}}$

\begin{tabular}{|c|c|c|c|c|c|c|}
\hline \multicolumn{2}{|r|}{ Model } & \multicolumn{2}{|c|}{ Unstandardized Coefficients } & \multirow{2}{*}{$\begin{array}{c}\text { Standardized } \\
\text { Coefficients } \\
\text { Beta }\end{array}$} & \multirow[t]{2}{*}{$\mathrm{T}$} & \multirow[t]{2}{*}{ Sig. } \\
\hline & & $\mathrm{B}$ & Std. Error & & & \\
\hline \multirow{3}{*}{1} & (Constant) & 217.865 & 35.761 & & 6.092 & .000 \\
\hline & ROE & 5.937 & 2.680 & .395 & 2.215 & .035 \\
\hline & DER & -37.207 & 19.556 & -.340 & -1.903 & .068 \\
\hline
\end{tabular}

Source: Data Processing Result of 2016

In the table I, it can be seen in column B of the constant and multiple linear regression coefficients for each independent variable. Based on the above values can be specified multiple linear regression model that is expressed in the equation, as follows:

$$
\mathrm{Y}=217.865+5.937 \mathrm{X}_{1}-37.207 \mathrm{X}_{2}
$$

Based on these equations can be seen that:

a. 217.865 constant value, this means that if the profitability and solvency unchanged or zero, then the value of the stock price of $\operatorname{Rp} 217.865$.

b. The coefficient of profitability by 5937 , this value indicates that every increase in profitability of $1 \%$, it will cause an increase in the stock price of Rp 5,937 assuming solvency variable is constant or zero.

c. The coefficient of solvency amounting to 37.207 , this value indicates that each increase of $1 \%$ solvency, it will cause a decrease in share price of $\mathrm{Rp} 37.207$ assuming profitability variable is constant or zero.

Based on the results of research using application software IBM SPSS 21.0 for windows, show that profitability has positive influence on the share price, while the solvency does not affect the stock price. $\mathrm{T}$ test results showed that the profitability variable tcount of 2215, while the value t table, in this study was 2052, and thus $t_{\text {count }}>T_{\text {tabel }}$ or 2,215>2,052. As for the significance of $t_{\text {count }}$ is 0.035 , which means that the value is smaller than the real level of $5 \%$, or 0.035 $>0.05$ thus can be proved that the $\mathrm{H}_{01}$ is rejected and accepted meaningful profitability $\mathrm{Ha} 1$ positive effect on stock prices. Positive $t$ value indicates that profitability has a direct relationship with stock prices.

For the test results to the variable $\mathrm{t}$ solvency indicates that the $t$ value at -1903 , while the value $t_{\text {tabel }}$, in this study was 2052, and thus $t_{\text {count }}$ smaller than $t_{\text {tabel }}$ or $1,903<2,052$. As for the value of the significance of $t_{\text {count }}$ is 0.068 , which means that the value is greater than the significance level of $5 \%$, or $0.068>0.05$ thus it can be proved that the $\mathrm{H}_{02}$ received and $\mathrm{H}_{\mathrm{a} 2}$ rejected which means solvency of have no effect on the stock price. Value $\mathrm{T}$ negative shows that the solvency have an opposite relationship with the direction of the stock price.

Development of profitability as measured by return on equity (ROE) in the oil and gas company in Indonesia which is listed on the Stock Exchange in 2010-2015 have increased and decreased, but the trend tends to decrease the company's profitability.

Moreover, the development of solvency as measured by Debt to Equity Ratio (DER) on oil and gas companies in Indonesia listed on the Stock Exchange in 2010-2015 have increased and decreased, but the trend is likely to increase despite the company's solvency in the last 2 years has decreased thin.

In this case, when the company is able to generate profits or to increase profits, stock prices will rise, in other words the profitability would increase stock prices [17]. Usually the stock is very influenced by the financial performance of the company concerned [18]. Profitability is one indicator of financial performance is generally considered to be investor in making an investment decision.

If the condition of the company categorized favorable or promising advantage in the future so many investors will embed their money to buy shares, of course encourage the stock price up to be higher. The results of this study which states that the profitability of positive effect on the stock price powered by research Jufrizen 2012 [19], Alep Pradipta Abimantrana 2013 [20], and Diana Erawati 2015 [21], which States that the Return on Equity (ROE) effect of positive and significant for stock prices.

Results of solvency is not influential on stock prices, is not in line with the theory expressed by [22] says that one of the factors that may affect the stock price movements is the proportion of the company's debt to equity". When oil and gas company solvency as measured by Debt to Equity Ratio (DER) has 
decreased, then it will not affect the stock price increases. However, the results of this study are supported by a previous study conducted by Eka Herawati 2008 [23] and Alep Pradipta Abimantrana 2013 [24], which states that the Debt to Equity Ratio (DER) has no effect on stock prices.

\section{CONCLUSIONS}

Based on the discussion and the results of the research was conducted on the influence of the profitability of measured with a Return on Equity (ROE) and the solvency measured with Debt to Equity Ratio (DER) of the stock price on oil and gas companies in Indonesia listed on the Stock Exchange 2010-2015 by using the analysis of verification as well as linear regression multiple, the conclusions in this study the profitability of positive effect on the stock price, which means that when the profitability of a company that measured by ROE rises, then the then the stock price of the company will rise, while the solvency no effect on the stock price which means that if there is a decrease in the solvency company, it will no effect on the company's stock price increases.

Overall, to improve profitability of measured with a return on equity (ROE), oil and gas company should use capital with efficient carried along with the increase working capital or investment. Funds are expected to be used optimally, so if well run the profits will increase. The company also can do the evaluation of the proportion of debt to equity expected cost of the company is financed with capital, so as to press the number of debt. In this case, the expected that the proportion of debt oil and gas company can be derived. However, no company that has no debt, so to do the company in the presence of the debt, the company increase profits with existing debt. Therefore, the company should be able to use the debt optimally. So, if investors to see the proportion of debt with capital then right shareholders to get a dividend would large because the company's obligation to pay the debt not too much.

Expected if the company wants to increase the share price performance of the company should be either by means meningkkatkan profitability and lowering solvency. So that the profitability and solvency will be a consideration of investors to embed shares. If it can be done by the company, investors will be interested in investing in oil and gas companies as a result of a good assessment of the investor to the company performance, due to the good performance of the company, investors can ensure prosperity.

\section{REFERENCES}

[1] Amir Dadrasmoghadam and Seyed Mohammad Reza Akbari. 2015. Relationship between Financial Ratios in the Stock Prices of Agriculture-Related Companies Accepted On the Stock Exchange for Iran. Research Journal Of Fisheries And Hydrobiology, Vol.10 No.9.
[2] Alep Pradipta Abimantrana. 2013. The Influence Of Financial Performance On Stock Price Around Publication Date Of Financial Statements (A Study In Food And Beverages Companies Listed On BEI) Periode 2010-2012.

[3] Fahmi, Irham dan Lavianti, Yovi. 2009. Teori Portofolio dan Analisis Investasi. Bandung: Alfabeta.

[4] Gitman, Lawrence J. dan Joehnk D Michael. 2010. Fundamental of Incesting. $11^{\text {th }}$ Edition. Boston: Pearson, Addison Wesley.

[5] Wahyudi, Untung dan Hartini P. Pawestri. 2006. Implikasi Struktur Kepemilikan Terhadap Nilai Perusahaan: Dengan Keputusan Keuangan Sebagai Variabel Intervening. Simposium Nasional Akuntansi (SNA) IX Padang.

[6] Brigham, E.F.dan Gapenski, Louis C. 2006. "Financial Management : Theory \& Practice. Orlando: The Drydeen Press

[7] Husnan, Suad dan Enny Pudjiastuti. 2007. Dasar-Dasar Manajemen Keuangan. Edisi 7. UPP STIM YKPN. Yogyakarta.

[8] Fahmi, Irham. 2014. Analisis Laporan Keuangan. Bandung: Alfabeta.

[9] Darsono, Azhari. 2005. Pedoman Praktis Memahami Laporan Keuangan. Andi: Yogyakarta

[10] J.Fred Weston dan Eugene F. Brigham (2010). Dasar-Dasar Manajemen Keuangan. Jakarta: Erlangga

[11] J.Fred Weston dan Eugene F. Brigham (2010). Dasar-Dasar Manajemen Keuangan. Jakarta: Erlangga

[12] Arifin, Ali. 2007. Membaca Saham. Yogyakarta: Andi

[13] Gitman, Lawrence J. dan Joehnk D Michael. 2010. Fundamental of Incesting. $11^{\text {th }}$ Edition. Boston: Pearson, Addison Wesley.

[14] Anoraga, Pandji dan Piji Pakarta, 2006. Pengantar Pasar Modal, Edisi Revisi. Jakarta: Rineka Cipta.

[15] Kasmir. 2010. Analisis Laporan Keuangan. Jakarta : Rajawali Pers

[16] Jogiyanto. 2003. Teori Portofolio dan Analisis Investasi. Edisi 2003. Yogyakarta : BPFE.

[17] Husnan, Suad dan Enny Pudjiastuti. 2007. Dasar-Dasar Manajemen Keuangan. Edisi 7. UPP STIM YKPN. Yogyakarta.

[18] Anoraga, Pandji dan Piji Pakarta, 2006. Pengantar Pasar Modal, Edisi Revisi. Jakarta: Rineka Cipta.

[19] Jufrizen. 2012. Pengaruh Rasio Profitabilitas Terhadap Harga Saham pada Perusahaan yang Tercatat dalam LQ45 di Bursa Efek Indonesia. alam LQ45 di Bursa Efek Indonesia. Jurnal Visioner \& Strategis. Volume 1, Nomor 2, p. 197-211.

[20] Alep Pradipta Abimantrana. 2013. The Influence Of Financial Performance On Stock Price Around Publication Date Of Financial $\quad$ Statements (A Study In Food And Beverages Companies Listed On BEI) Periode 2010-2012.

[21] Diana Erawati. 2015. Pengaruh Likuiditas, Manajemen Aset, Manajemen Liabilitas, Dan Profitabilitas Terhadap Harga Saham Pasar Pada Perusahaan Makanan Dan Minuman Yang Terdaftar Di BEI Periode Tahun 2008 - 2012. e-Jurnal Ilmu Manajemen MAGISTRA Vol. 1 No.1.

[22] J.Fred Weston dan Eugene F. Brigham (2010). Dasar-Dasar Manajemen Keuangan. Jakarta: Erlangga

[23] Hermawati, Eka. 2008. "Pengaruh Rasio Keuangan Terhadap Harga Saham Perusahaan Agroindustri yang Terdaftar Pada Indekx LQ45 di Bursa Efek Indonesia”. Jurnal Universitas Gunadarma. Jakarta

[24] Alep Pradipta Abimantrana. 2013. The Influence Of Financial Performance On Stock Price Around Publication Date Of Financial Statements (A Study In Food And Beverages Companies Listed On BEI) Periode 2010-2012. 